University of Wollongong

Research Online

Faculty of Law, Humanities and the Arts Papers (Archive)

Faculty of Arts, Social Sciences \& Humanities

$1-1-2007$

Paternalism and complicity: or how not to atone for the 'Sins of the Father'

Fiona Probyn-Rapsey

University of Sydney (USYD)

Follow this and additional works at: https://ro.uow.edu.au/lhapapers

Part of the Arts and Humanities Commons, and the Law Commons

Research Online is the open access institutional repository for the University of Wollongong. For further information contact the UOW Library: research-pubs@uow.edu.au 


\title{
Paternalism and complicity: or how not to atone for the 'Sins of the Father'
}

\begin{abstract}
The cultural politics of Australian colonialism revolve around discourses of paternalism and the ' protection' of Aboriginal people. Understanding how paternalism reproduces itself transgenerationally, and between whites and Aboriginal people, between subordinated groups, between women, is one way to approach its limits. Starting with this premise, I examine the ways in which paternalism reproduces itself, such that even today white paternalistic attitudes towards Aboriginal people and culture are pervasive. I focus here on Mary Ellen Jordan's Australian memoir Balanda: My Year in Arnhem Land (2005), which is critical of, and complicit with, the biopolitical power of paternalism and its accompanying rhetoric of 'protection '. I read this memoir within the context of a broader, shifting genealogy of protection within Australian cultural history, teasing out some of the implications of the capacity of paternalism to mutate and to retain its cultural and political influence.
\end{abstract}

\section{Keywords}

atone, not, father, complicity, sins, paternalism

Disciplines

Arts and Humanities | Law

\section{Publication Details}

Probyn-Rapsey, F. (2007). Paternalism and complicity: or how not to atone for the 'Sins of the Father'. Australian Literary Studies, 23 (1), 92-103. 


\section{FIONA PROBYN-RAPSEY}

\section{Paternalism and Complicity: Or How Not to Atone for the 'Sins of the Father'}

$\mathrm{T}$

1 HE cultural politics of Australian colonialism revolve around discourses of paternalism and the 'protection' of Aboriginal people. Understanding how paternalism reproduces itself transgenerationally, and between whites and Aboriginal people, between subordinated groups, between women, is one way to approach its limits. Starting with this premise, I examine the ways in which paternalism reproduces itself, such that even today white paternalistic attitudes towards Aboriginal people and culture are pervasive. I focus here on Mary Ellen Jordan's Australian memoir Balanda: My Year in Arnhem Land (2005), which is critical of, and complicit with, the biopolitical power of paternalism and its accompanying rhetoric of 'protection'. I read this memoir within the context of a broader, shifting genealogy of protection within Australian cultural history, teasing out some of the implications of the capacity of paternalism to mutate and to retain its cultural and political influence.

In Jordan's memoir, a young white Australian woman working for a community cultural centre in Maningrida, a remote Aboriginal community in Arnhem Land, becomes increasingly sceptical of her role as white 'protector' of Aboriginal culture. The memoir traces her growing resentment at what she calls the 'protection racket' that whites offer Aboriginal people. 'In her view this 'protection' is self-serving because it fails to protect Aboriginal people from white domination, while it stymies Aboriginal 'self determination'. In Jordan's judgement, the 'protection racket' in Maningrida in fact gives more opportunities to whites than to Aboriginal people, as well as entrenching poverty in the Aboriginal community. When she expresses her views to another white resident he replies, 'When you're a bit older and you've been around as long as me, you'll realise that these people have to be protected from themselves' (206). Jordan comes to believe that the 'threat' to the community does not come from within but from white paternalism.

In Maningrida, Jordan is 'in a world that seemed utterly foreign to me' (21), and feels like she had 'never been part of such a small minority before - there were 100150 Balandas [non-indigenous] in a community of around 1500' (18). She had 'expected the community to be a mish-mash of black and white - but in fact there was a sharp social divide' (8). She is offended at the first dinner party she is invited

1 There are echoes of Judith Stiehm. See her Women and Men's Wars (New York: Pergamon, 1983) and Arms and the Enlisted Women (Philadelphia: Temple UP, 1989). 
to, where another Balanda tells her that the place is a good one 'as long as you don't have to mix with the locals' (36). On the whole, Jordan finds those holding such explicitly racist views are outnumbered by people who have what she describes as a 'positive' racism of romanticisation: 'In Balanda thinking, Aboriginal people could be elevated and mythologised in a way that seemed to take away their status as real people' (147). The consequence is that their 'failure' to live up to the romantic image opens up the possibility for discrimination. Beth Povinelli's argument about the image that underpins Native Title Legislation supports this view: she observes that the love of the 'traditional' Aboriginal constructs Aboriginal people as 'failures of ... the very identity that identifies them' (29).

The discourse of 'self-determination' has, from the $1970 \mathrm{~s}$, been the dominant rhetoric of Aboriginal governance. Jordan had been expecting a community which functioned according to this idea (9) because it had been founded on 'post-Whitlam ideals of land rights and self-determination' (92). Instead, she found that things 'rarely ran in an Aboriginal way in Maningrida. I had expected to be surrounded by the exotic, but instead I was enmeshed in white bureaucracy, a jungle of Latinate terms like acquit, triplicate and application' (91). For her, the measure of the success of self-determination would be separation, 'rupture', a term Tim Rowse uses in his critique of the policy: "people are being asked to be self-determining within social forms bequeathed by an era of "assimilation." The resources they have to work with, both material and rhetorical, are too far rooted in our shared pasts to justify celebrations of rupture with the bad old days' (10).

In her critique of the protection racket, Jordan taps into one of Australian colonialism's key concepts. Protection - paternalism's key term - is deeply embedded in white thinking when it comes to Aboriginality. ${ }^{2}$ Balanda illustrates the way in which growing up white involves the accumulation of paternalistic attitudes towards Aboriginal people, as if it is built into the very fabric of the subject position 'white Australian'. It is important to note that this is not, in any simple sense, a conservative attitude, but informs liberal attitudes as well. Talking to her friend in Melbourne, Jordan recounts:

We had talked a lot about Aboriginal issues over the years, trying to figure out what we thought, what was right and what ought to be done. We had worked out a framework

2 The Australian colonies were quick to make 'Protection' a bureaucratic preoccupation. 'Protectors' of Aborigines - and the word is most frequently in scare quotes to signal its deadly irony - were appointed in South Australia (founded in 1835) and Victoria (1838). George Augustus Robinson was the first Chief Protector of the Port Philip District in 1839 and more famously Protector of Aborigines in Tasmania. Official Protectors were appointed much later in Queensland (1897; see Rosalind Kidd, The Way We Civilise: Aboriginal Affairs - the Untold Story [St Lucia, Qld: U of Queensland P, 1997], p. 13) and New South Wales, which appointed its first official protector in 1881. This position was abolished with the introduction of the NSW Aborigines Protection Act 1909-1943 which established the Aborigines Protection Board, renamed the Aborigines Welfare Board in 1943. The Protection Boards were set up to monitor and regulate the lives, including marriages, births, work and residence of Aboriginal people and those associated with them. 
for understanding Aboriginal issues that was typical of the young, left wing, socialjustice-oriented people we knew. It was clear to us that because Aboriginal people had been wronged by the white invasion, the Australian government ought to give them as much money as it would take to fix or alleviate the problems that colonisation had caused. The social problems like domestic violence and alcohol abuse, health problems like diabetes and heart disease, economic problems, language loss - all of these should be tackled by government programs, because we owed it to Aboriginal people. Before I went to Maningrida, it hadn't occurred to me that 'solutions' that came from the outside would be so ineffective. (88-89)

Jordan describes the way in which a paternalistic relationship to Aboriginality formed an anchor for her white identity and her politics. She describes herself as having a 'strong but unfocussed social conscience' (160), which is supplemented by a 'medley of white guilt, ignorance and earnest but unfocussed respect' (185).

In the face of a subordinated community Jordan initially sees some direction for herself, recounting that she had felt that the Aboriginal community in Maningrida needed protection from non-indigenous culture: 'we thought that Aboriginal cultures were intrinsically worth preserving. By taking on the Balanda aspects of their lives for them, we wanted to protect Aboriginal people from contamination by the dominant culture' (91). 'Contamination' means the decline of traditional cultures; 'decline' is a key term for inviting protection:

I had come to Maningrida with similar romanticised perceptions, thinking that Aboriginal cultures and languages could remain intact, maybe even thrive, if only they were protected by a buffer of benevolent white people. I thought that it was appropriate for Balandas to do the work, because the role of 'being Aboriginal' was important and significant in itself, and should not be impinged on by Balanda style work. (148-49)

This rhetoric gets to the heart of the paradox of protection: to protect from the thing that one is is not protection so much as a confirmation of domination.

In the context of feminist readings of women's subordination, Wendy Brown notes that "to be "protected" by the very same power whose violation one fears perpetuates the very modality of dependence and powerlessness' (170). Jordan comes to see 'protection' in similar terms, and reconfigures her 'good intentions' as 'wounding' (91). Later, she says, 'our good intentions were patronising, and ... our underlying assumptions about Aboriginal people reinforced their passive position and our right to make decisions on their behalf' $(148-49)$. This critique renders Jordan's text postcolonial rather than colonial, for it is both critical of and complicit with past practices.

What is fascinating about this memoir is that Jordan locates 'the problems' afflicting the community within the discourse of 'protection', whilst continuing to occupy a paternalistic position, often speaking 'in the best interests' of those who do not speak: 'Sometimes I felt that the best I could say of the role of Balandas in Maningrida was that we were paternalistic. The worst was that the system we worked within prevented Aboriginal people from taking responsibility for 
themselves and their communities' (218-19). The memoir identifies paternalism as a condition of the recent past - 'we were paternalistic', 'were patronising', 'reinforced their passive position' - but shows that the paternalism remains. The paternalism manifests in Jordan's diagnosis of the failures of 'self determination', though positioned primarily as a failed white policy, relies on a reading of Aboriginal 'failure-to-be-self-determining' within terms set by and understood by whites. To put it another way, Jordan, as a white woman, is not in a strong position to judge the success or failures of self-determination for Aboriginal people, and each time she protests the domination of the system she works within, she reiterates a paternalist position, a paradox that the policy of 'self-determination' sets up. Noel Pearson's work is cited as support for her observations, but we hear little from the people that the system fails. It could be argued that this silence reflects the nature of their subordination, but it is more the case that paternalism structures that engagement in the first place; as such, Jordan's reference to Pearson, a paternalist of a different sort from within the Cape York community, is apt and unsurprising. They are both disappointed with the lack of difference, the lack of a rupture between the 'bad old days' (pre-Land rights, citizenship rights) and the creation of welfare systems designed to support communities.

By and large the memoir does not engage with the question of how Jordan's view might differ from the views of the Aboriginal people with whom she works. However, the epilogue provides a potentially different perspective on the protection racket she describes. Jordan recounts Valerie 'mimicking the way Balandas reacted to her, and then she laughed her head off. I remembered looking at her in astonishment. She was playing with the notion of Aboriginal mystique. She knew what the Balandas thought about her, and about themselves: she was onto us' $(220)^{3}$ Jordan's look of astonishment, as well as the realisation that 'she was onto us', end the book and also challenge it, being two of very few indications that the passivity and dependency Jordan diagnoses could be read differently. Ending here, the ramifications of Valerie's mimicry are foreclosed, protecting paternalism from the implications of its dependency on the 'helped'. Had this 'astonishment' come earlier, it might have provoked dialogue on a different plane, not of failure but of 'response-ability' and a reconsideration of different types of dependency, including dependency as a condition of sociality and subjectivity. ${ }^{4}$

3 'Mimicry', Homi Bhabha has noted in 'Of Mimicry and Man', is a powerful subversion of colonial power where the colonised comes to 'resemble but menace' the colonisers (127). It works on the basis of unsettling the coloniser's presumption that the colonised are, and aspire to be, easily read and positioned within the colonial hierarchy.

4 Jordan's 'astonishment' at seeing Valerie's 'play' is the astonishment of the writer who, in telling the 'history of the Other' is 'pushed against the limits of ... [her] own' (Sara Suleri, The Rhetoric of English India [Chicago: U of Chicago P, 1992], p. 2). The style of the memoir, in proceeding towards a political argument about self-determination rather than offering a meditation on whiteness or intercultural dialogue, shuts down what this scene might have opened up. 
Dependence needs to be rethought, not in terms of its 'familial' or paternalistic structure of parent/child - a process in which the 'subjectivity' of the latter is formed in relation to the former - but as a relationship between different subjectivities in an intercultural dialogue. Kelly Oliver writes,

the ethical subject as witnessing subjectivity acknowledges her dependence upon her addressee and interlocutor whom she cannot possess but upon whom she is absolutely dependent for her very subjectivity. This moment is the moment of ethical selfconsciousness for the witnessing subject. It is the moment in which the subject realises that an ethical obligation to others is built into the condition of possibility for subjectivity. (325)

Subject positions always qualify the potential of ethical relationships. In Australia, the subject position of the white woman is still coded in terms of the 'helper' and, according to Aileen Moreton-Robinson, is still largely unconsciously complicit with white colonialism. Jordan's text announces a missed opportunity to extend a critique of protection to a critique of structures of colonialism and whiteness itself.

Tim Rowse's White Flour, White Power argues that the system of rationing did not simply accompany the colonial relationship, but articulated it. Consequently, Rowse finds that ""pauperism" is one of the central concepts of Australian colonialism' (40), and that such descriptions became prescriptive. He points out that the term 'pauper' is a 'term of moral and political disapproval, used by would-be helpers to describe the lack of co-operation of the poor with philanthropy's conditions' (40). In their genealogy of dependency, American critics Nancy Fraser and Linda Gordon find that in post-industrial societies dependency is 'feminized and racialized; the new psychological meanings have strong feminine associations, while currents once associated with the native and slave are increasingly inflecting the discourse about welfare' (25). Such a critique seems pertinent to Jordan's and Pearson's concerns about passive welfare protection: Jordan writes, 'Aboriginal people were making us indispensable: they had no intention of taking on our jobs and worries when there was no earthly need to do so' (95). On this basis, she worries about a time in the future when

the government funding was cut, or when for some reason there were no Balandas willing to come to Arnhem Land and do the community's work for it. Most of the Aboriginal people there had never known a time without a benevolent Balanda presence in their lives, and without the flow of government money into their hands. (95)

In the critique and description of passivity there is also prescription: 'they had never known'. But presumably 'they' know things other than what Jordan knows about them, as Valerie's mimicry suggests.

My concern here, though, is not to focus on arguing against the political trajectory of the memoir and its echoes of Noel Pearson's Our Right to Take Responsibility, nor even in tracing the gaps and silences for alternatives to Jordan's view of the 
'protection racket'. Rather, what interests me is the ways in which the memoir might help to understand how paternalism reproduces itself. As I indicated earlier, the question is not the extent to which paternalism pervades Australian culture, but understanding its capacity to transmit itself amongst whites, particularly.

Jordan's desire for liberal-inflected atonement brings her into a paternalistic relationship which she initially adheres to: 'We accepted the system that we inherited, and assumed that eventually, with education, Aboriginal people would step into the jobs now done by Balandas' (92). What interests me is that paternalism was, for Jordan, initially a 'good' and therefore accepted or acceptable inheritance, while colonialism came to be associated with the 'bad' past and with the 'sins of the father'. How did paternalism occupy the space of the 'good' here? And how does it appear to be separate from colonialism, when in fact it is a means by which colonialism is articulated? What is the dynamic that allows white Australians to reproduce paternalism, still believing themselves to be 'good'?

To consider this question, we need to consider what kind of 'power' paternalism is, and the relationship of that power to more frequently contested forms of colonial violence. Paternalism is biopolitical power, or biopower, power that does not kill but which cultivates life in particular forms (Foucault). Foucault did not complete his work in relation to outlining how this system of power operates, but others have gone on to define the concept. For the purposes of my reading of Balanda, and analysis of Australian colonialism more specifically, I have found the elaboration of Foucault's work by Rabinow and Rose to be particularly useful. They describe biopolitics as containing the following features:

Strategies for intervention upon collective existence in the name of life and health, initially addressed to populations that may or may not be territorialized upon the nation, society or pre-given communities, but may also be specified in terms of emergent biosocial collectivities, sometimes specified in terms of categories of race, ethnicity, gender or religion. Modes of subjectification, in which individuals can be brought to work on themselves, under certain forms of authority, in relation to truth discourses, by means of practices of the self, in the name of individual or collective life or health. (2-3)

Paternalism is biopolitical in the sense that it works to focus on the 'health' of the individual, in their best interests, as collective group, even those ambivalently placed within the nation. Biopolitics include a positive affirmation of health, life and longevity, but this mode is not characteristic of 'settler' or colonial power only, which is why Aboriginal leaders inhabit the biopolitical while contesting its administration (see Pearson).

Paternalism is characterised by domination coupled with love and affection, where one party, which assumes superiority, purports to act 'in the best interests' of the subordinate. Its roots are in an image of a family projected onto an institution like a sovereign or government. Jack D. Douglas argues that 'maternalism and paternalism have always been among the most successful of devices of self- 
presentation by those who wish to influence others' (172). Paternalism then, as a form of power, predicates what George Lakoff sees as 'part of our standard conceptual repertoire', which is the 'nation as family'. This trope or metaphor of political community takes a particularly strong form in colonial societies, where the colonised are positioned as children - indeed, Protection boards in Australia often made reference to their positioning as acting in loco parentis. The stolen generations would have to be the most obvious expression of the 'nation as family' trope in the control of Aboriginal people: the State represented children who were parent-less, and then could be 'taken' in by the surrogate father state.

Douglas argues that there is a crucial distinction between what he calls 'genetic paternalism' and 'state paternalism', and that 'genetic paternalism is by far the most important form of sincerely cooperative paternalism' (174). He defines 'genetic paternalism' as 'any form of paternalism (doing good for others in the name of "what is good for them") in which those acting paternally are sincerely acting to help the other person become more independently competent over the long run' (174). In contrast, 'conflictful paternalism' 'is any form of paternalism that is not aimed at the long run independent competence and equality of the submissive member of the relation' (174). This is the kind of paternalism that Jordan is so disappointed to find in Maningrida's white and Aboriginal relationships. By contrast, Mary R. Jackman reads paternalism as 'discrimination without the expression of hostility' (10), arguing that the emphasis on 'conflict' in social science readings of power inequality often results in scholars overlooking the more subtle forms of 'consensual' or even cooperative power. She suggests that there is an 'inconsistent attitude structure', of love and domination, 'that lies at its core' and which enhances the 'dominant group's ability to practice discrimination' (273). It is this 'inconsistency' and incoherence that makes paternalism so much less likely to come under scrutiny than open hostility and violence.

In the context of these observations, the recent 'History Wars' are of particular interest. Debate centres on a dispute over the level of violence by settlers against indigenous people. The main antagonists have been the self-published and selfproclaimed public intellectual Keith Windschuttle, who argues for a 'benign colonisation' rather than a violent one, and academic historians like Henry Reynolds and Lyndall Ryan, whose work did much to establish (in scholarly terms) the level of conflict across Australia. Much of this debate has focused on the frontier violence of dispossession, the number of dead, because this, as both sides would agree, reflects on the 'national character', 'who we are as a people'. As Patrick Brantlinger points out, 'The history of British Imperialism around the world does not support Windschuttle's belief that it was mainly benign, or that it was somehow effectively restrained by a humanitarian and religious culture on the frontiers in North America, Australia and elsewhere' (669). 
Windschuttle's arguments, and those of some of his critics, are based on privileging the benevolent practice of colonialism associated with the missions, the evangelical protection of 'god's children', over violent dispossession. Paternalism, on the other hand, is much less spectacular, much more mundane; it is not about the risk of death on the frontier, but the maintenance of life in a particular form. As Jordan says, 'It wasn't an ochre-coloured frontier adventure for me or my friends or colleagues. It was every day life' (213). So, too, paternalism is about 'everyday life' and we miss it if we focus exclusively on the violent frontier as colonialism's principal character. While it is tempting to say that protection is a 'lesser evil' compared with the physical violence of warfare and indiscriminate killing, the point is that biopolitical power recoils at waste of life. Thus, it seeks to maintain it in a particular form: on a reservation, sober, willing to trade, monogamous, disease free, and as knowing British subjects. ${ }^{5}$ As well as the question of genocide, it would be fruitful to also consider how colonialism in Australia sought to 'maintain' the life of Aboriginal people in particular forms, thus rendering suspect any recourse to an argument based on a presumed 'benign' colonisation. It is not a matter of genocide or protection, but rather a question of genocide and protection.

The work of feminist philosophers, including most recently Iris Marion Young, suggest that the idea that violation precedes protection in a temporal or chronological order is wrong because, in a crucial sense, violation and protection have a complicated entanglement. The presumption that violence precedes protection implies a moral order, with the 'first' kind of violence appearing worse than the 'second'. Such thinking, while understandable, underplays the complexity of their interdependence, or complicity: in Australian colonialism, protective paternalism controls and enables through controlled proximity to violence. This proximity is protection's problem, and its raison d'être. It cannot escape the violence it is supposed to buffer; it is complicit with what it seeks to ameliorate. Perhaps because of this complicity, paternalism might usefully be thought of in terms of the pharmakon, being simultaneously poison and cure (Derrida). This is the paradox at the centre of Jordan's memoir, which functions as a diagnosis of the problem of white paternalism that does not see that such a white diagnosis is not only a cure, but also the poison. This paradox brings us back to the issue of paternalism's capacity to transmit itself.

5 One Chief Protector, Dr Cecil Cook in the Northern Territory (1927-1939) seems to have appreciated this complicity. Cook described the role of Protector by reference to the 1864 expedition from Adelaide into country that is now the Northern Territory. Dr F.E. Goldsmith was appointed to 'prevent the affliction of the native people with imported communicable diseases. ... He was to foster friendly relations and offer inducements to them to work, to encourage trade, and to police scrupulous discharge of obligations to them. He was to make them comprehend their privileges and responsibilities as British subjects to prevent interference with their women or their debauchery with liquor, and to control the issue of relief rations' (560-61). 
Jordan's own relationship to her father is significant here. In the middle of her memoir, when she is busy attempting to 'atone for the sins of our fathers', her own father dies. With this news she experiences some relief, having been estranged from him for some years because of the violence of his relationship to the family:

On hearing the news of his death, my sister told me, one of our other sisters had said to another, 'Maybe now we can stop having nightmares.' I put the phone down and walked quietly past the dinner table and out the door. Once I was outside, I began to cry. The tears were not for the loss of a man I barely knew, but for the pain of a childhood spent in fear of his violence, for the scars that he had left on me and my brothers and sisters, for the sadness and grief that had come with the absence of a loving father and the presence instead of this terrifying man. (125)

The reader may surmise that Jordan resisted the violence of her own father in order to become a different kind of citizen, one who sought to 'help' the vulnerable rather than to create them. While Jordan appears to hold that she is not dominated or defined by her relationship with her violent father, she is still affected by his absence, his shadow and alternative (125). Jordan takes up this position of the 'loving father' in relation to Aborigines, thus substantiating the absence that she grieves for. Her violent father operates as Other to this 'loving father'.

Young points out that, within the logic of protection, dominant men are 'bad men' while 'good men' are those who protect $u s$, infantilised women and children, from them, aggressive masculine violators (4). This model positions women and children within an economy of paternalism, caught between the dominance of aggressive men and the protection of carers. Consequently, as Young points out, 'dominative masculinity in this way constitutes protective masculinity as its other' (4). Building on the work of Mohanty and Narayan, Young makes the point that western feminists have utilised this framing to situate themselves as carers or 'loving protectors' (Paisley), as opposed to aggressive masculine types. The logic of protection and paternalism requires conflict, threats of violence, in order that other forms of colonial domination pass as 'good'. It is this relationship between conflict and consensus, threat and protection, bad and good, which is the key to understanding how paternalism reproduces itself. It is not through total rupture, for the end to violence would equate to no role for the protector; where then would whiteness go?

In terms of Australian colonialism, this argument has a number of ramifications. Colonial paternalism situates itself as the good protector, precisely when it represents past violence as that to which it stands in apparent contrast. In Jordan's references to the 'sins of the father', it appears that she too takes up this rhetoric of feminine care versus masculine violence, only to reveal its instability. The failure of the 'loving father' to 'help' is positioned in the memoir as an Aboriginal failure as much as the failure of whites, who do not realise that the nation is not a family. The death of the father/s - Jordan rhetorically kills off the 'loving father' in Balanda by her rejection of protection - is recounted in the midst of an episode in which Jordan 
is sexually harassed and stalked by an Aboriginal man. This leaves her very frightened and she eventually has to leave her flat. The domestic violence that she recalls from her childhood and the violence threatened by the Aboriginal man are both instantly recognisable as requiring protection against. But as Jordan discovers, the rhetoric of protection is closely aligned to the violence that it opposes. In response to Archie's offer to build a wire mesh screen around her flat, Jordan responds: 'I didn't want to live in a cage. But I did want to be safe' (122). The point here is not that the harassment is like a cage, but to show that these terms, violence and protection, are twins; they operate, double-helix like, at the heart of paternalism itself, splitting, doubling and coming together again and again.

The colonial paternalism expressed by Jordan is committed to change, to remedy and redeem, to participate in a rupture with that past and to be the loving father as opposed to the violent one. Its commitment reflects the idea that responsibility for historic injustice is inherited along 'family lines' (Thompson). But in a country where whites assume the position of cultural managers, such inheritances can include paternalistic interventions. Paternalism attaches itself to the past and to projected 'sins of the father', drawing it closer to the violation it is committed to protect others from. It is dependent on constructing the 'problems' of colonialism as located with particular elements (for instance 'white invasion' in the past, or the 'mother country') rather than with the ongoing structure of colonisation. This suits the logic of protection yet again, for it is not a discourse that seeks to alter the structure; rather, it attempts to install a complementary form of disciplinary power, a biopolitical power, which seeks to maintain life in a particular form. The constant division or mitosis of violation/protection is the dynamic behind paternalism. Between violation and protection there is complicity; it is complicity that joins these two things together, complicity in the sense of being an accomplice, and in the sense of complexity of involvement.

Jordan's 'shame' as a white Australian critic of colonialism does not do justice to the structural nature of colonialism: 'I was disgusted with myself for buying into it and made an effort to stop' (139). Shame is, as Sara Ahmed notes, a temporary, fleeting thing that suggests a getting over in order to enter into pride (107, 109-10). In Craft for a Dry Lake Kim Mahood confesses her shame in using her skin name 'to claim a certain credibility among urban friends for my knowledge of Aboriginal society' (125). Mahood and Jordan contextualise the 'shame' of their possessive interest in Aboriginality, where the white knowers of Aboriginality congratulate themselves on their capacity to know the Other, without the Other ever having to speak. Rather than shame, it might be more useful to think of complicity. Complicity appeals to the structural as much to the personal, momentary condition of response-ability (Probyn-Rapsey; see also Sanders).

Paternalism operates as a key term in Australian postcolonialism and maintains this presence by its iterability. Key to the reproduction of paternalism is the ways in 
which it draws on the 'nation as family' trope, a trope that is deeply embedded in our political and moral imaginations (Lakoff), and one that, importantly, supports its biopolitical nature. Paternalism unites love, affection and power in a way that sometimes insulates it from critique. And paternalism necessitates the identification of repressive elements, the 'sins of the father', the 'bad old days', in order to situate itself as a preferred model. This dynamic produces iterability, repetition with a difference. Balanda makes clear that the desired rupture between violence and protection is continually deferred, and that the terms lie in a complicit relationship within paternalism.

\section{WORKS CITED}

Ahmed, S. The Cultural Politics of Emotion. Edinburgh: Edinburgh UP, 2004.

Bhabha, Homi. 'Of Mimicry and Man: The Ambivalence of Colonial Discourse.' October 28 (1984): 125-33.

Brown, Wendy. 1995. States of Injury: Power and Freedom in Late Modernity. Princeton: Princeton UP, 1995.

Brantlinger, Patrick. 'Black Armband versus White Blindfold History in Australia.' Victorian Studies (Summer 2004): 655-76.

Cook, Cecil. 'Medicine and the Australian Aboriginal: A Century of Contact in the Northern Territory.' Medical Journal of Australia (April 1966): 559-65.

Derrida, Jacques. Dissemination. Trans. Barbara Johnson. Chicago: U of Chicago P, 1981.

Douglas, Jack. 'Cooperative Paternalism versus Conflictful Paternalism.' Paternalism. Ed. Rolf Sartorius. Minneapolis: U of Minnesota P, 1983. 171-200.

Foucault, Michel. 'Society must be defended': lectures at the Collège de France, 1975-76, Michel Foucault. Ed. Mauro Bertani and Alessandro Fontana. Trans. David Macey. London: Allen Lane, 2003.

Fraser, Nancy, and Linda Gordon. 'A Genealogy of Dependency: Tracing a Keyword of the US Welfare State.' The Subject of Care: Feminist Perspectives on Dependency. Ed. Eve Feder Kittay and Ellen K. Feder. Oxford: Rowman and Littlefield, 2002. 14-39.

Human Rights and Equal Opportunity Commission (HREOC). Bringing them Home: Report of the National Inquiry into the Separation of Aboriginal and Torres Strait Islander Children from their Families. Sydney: HREOC, 1997.

Jackman, Mary R. The Velvet Glove: Paternalism and Conflict in Gender, Class and Race Relations. Berkeley: U of California P, 1994.

Jordan, Mary Ellen. Balanda: My Year in Arnhem Land. Sydney: Allen \& Unwin, 2005.

Lakoff, George. Moral Politics: How Conservatives and Liberals Think. Chicago: U of Chicago P, 2001.

Mahood, Kim. Craft for a Dry Lake. Sydney: Anchor Books, 2000.

Moreton-Robinson, Aileen. Talking Up to the White Woman. St Lucia: U of Queensland P, 2000.

Oliver, Kelly. 'Subjectivity as Responsivity: The Ethical Implications of Dependency.' The Subject of Care: Feminist Perspectives on Dependency. Ed Eve Feder Kittay and Ellen K. Feder. Oxford: Rowman and Littlefield, 2002. 322-34. 


\section{PATERNALISM AND COMPLICITY}

Paisley, Fiona. Loving Protection? Australian Feminism and Aboriginal Women's Rights 1919-1939. Carlton South, Vic.: Melbourne UP, 2000.

Pearson, Noel. Our Right to Take Responsibility. Cairns: Noel Pearson and Associates, 2000.

Povinelli, Elizabeth A. 'Settler Modernity and the Quest for an Indigenous Tradition.' Public Culture 11.1 (1999): 19-48.

Probyn-Rapsey, Fiona. 'Complicity, Critique, Methodology.' Forthcoming in Ariel: A Review of International English Literatures (2008).

Rabinow, Paul, and Nikolas Rose, 'Thoughts on the Concept of Biopower Today.' http://www.molsci.org/research/publications_pdf/Rose_Rabinow_Biopower_Today.pdf (accessed November 2004) 1-25, 2003.

Reynolds, Henry. Frontier: Aborigines, Settlers and Land. Sydney: Allen \& Unwin, 1987.

. Why Weren't We Told? A Personal Search for the Truth about our History. Ringwood: Viking, 1999.

Rowse, Tim. White Flour, White Power: From Rations to Citizenship in Central Australia. Melbourne: Cambridge UP, 1998.

Ryan, Lyndall. The Aboriginal Tasmanians. St Lucia, Qld: U of Queensland P, 1981.

Sanders, Mark. Complicities: The Intellectual and Apartheid. Durham: Duke UP, 2002.

Thompson, Janna. Taking Responsibility for the Past: Reparation and Historical Injustice. Cambridge: Polity, 2002.

Windschuttle, Keith. The Fabrication of Aboriginal History. Paddington, NSW: Macleay, 2002.

Young, Iris Marion. 'The Logic of Masculinist Protection: Reflections on the Current Security State.' Signs: Journal of Women in Culture and Society 29.1 (2003): 1-12. 